\title{
HTC2 Gene
}

National Cancer Institute

\section{Source}

National Cancer Institute. HTC2 Gene. NCI Thesaurus. Code C111821.

Human HTC2 gene is located within Xq24-q27.1 and the size of this phenotypic locus is not reported. This gene region has no known protein product. Palindrome-mediated interchromosomal insertion in this locus is associated with congenital generalized hypertrichosis. 